LOCAL WISDOM, 12 (1): $\operatorname{agmma,2020}$
Local Wisdom Scientific Online Journal
ISSN: 2086-3764

\title{
The Bamboo Greenhouse Technology for Hydroganic Plants with Independent Photovoltaic Energy in the Food Safety Program
}

\author{
Hery Budiyanto $^{*}$, Munanto Haris ${ }^{2}$, Aries Boedi Setiawan ${ }^{3}$, Elta Sonalitha ${ }^{3}$, \\ Muhammad Iqbal ${ }^{4}$ \\ ${ }^{1}$ Department of Architecture, University of Merdeka Malang, Indonesia \\ ${ }^{2}$ The Agricultural Research Center, Ketindan, Malang, Indonesia \\ ${ }^{3}$ Department of Electrical Engineering, University of Merdeka Malang, Indonesia \\ ${ }^{4}$ Department of Architecture, Graduate School, University of Merdeka Malang, Indonesia \\ Corresponding Author: : hery.budiyanto@unmer.ac.id
}

\begin{abstract}
Keywords: $\quad$ The development of the city has made a lot of agricultural land greenhouse, turned into residential land and other urban facilities so that hydroganic, solar agricultural land becomes increasingly narrow so that it can weaken energy, food the food safety program. Another way is needed to utilize narrow safety land in an effort to develop agricultural products, namely by farming and maintaining fish hydroganic. Hydroganic comes from the words "Hydro" and "Organic" which are defined as organic cultivation systems by combining the hydro system and the organic system. The research method uses a descriptive qualitative method, beginning with the design, the creation of an Independent Energy Hydroganic Greenhouse and the planting of vegetables and fish stocking. Retrieval of data in the form of observations and documentation of photos and videos on activities. Through this program the construction of a tunnel-shaped greenhouse with bamboo structure has been carried out successfully, 2 (two) hydroganic farming facilities complete with fish ponds, 1 (one) solar power generation unit consisting of 4 solar panels each with a capacity of $100 \mathrm{wp}$ with energy storage in the form of a $100 \mathrm{AH} 12 \mathrm{~V}$ battery and a $1000 \mathrm{WH}$ inverter in sunny conditions producing a minimum of $13.6 \mathrm{Amp}, 18.8$ $\mathrm{V}$ can meet the energy needs to drive the water circulation pump and greenhouse lighting lamps and the surrounding environment. Planting sla and mustard greens as well as spreading catfish and tilapia in mid-August 2019, lettuce vegetables can be harvested at the end of September 2019.
\end{abstract}

DOI: https://doi.org/10.26905/lw.v12i1.3676

@ 2017 The Authors. Published by GKAK UNMER Malang

*Corresponding Author: hery.budiyanto@unmer.ac.id 
The Bamboo Greenhouse Technology for Hydroganic Plants with Independent Photovoltaic

Energy in the Food Safety Program

Hery Budiyanto, Munanto Haris, Aries Boedi Setiawan, Elta Sonalitha,Muhammad Iqbal

\section{Introduction}

Agriculture is a very important sector for the people of Indonesia. The agricultural sector is a source of income for some people, because most of Indonesia's territory is agricultural land. Farmers usually use land for growing media, but along with the development of the city, a lot of agricultural land has been turned into residential land and other urban facilities so that agricultural land becomes increasingly narrow. To overcome this problem, many thought to utilize limited land is done, one of which is the concept of Urban Farming, namely agriculture with narrow land use or land intensification, to meet the needs of fresh vegetables and fruit every day for people in urban areas (Pratiwi, YI. at.al. 2017). So now there is another way to use narrow land as an effort to develop agricultural products, namely by planting with a hydropower system. Hydroganic comes from the words "Hydro" and "Organic" which are defined as organic cultivation systems by combining hydro systems and organic systems. The main source of nutrients from hydroganic is obtained from solid and liquid organic fertilizer and pond water which is treated as plant nutrition. There are 3 important components in hydraulics applications, namely: 1) Ponds; 2) organic fertilizer (as a planting medium); and 3) axis system series (Yeniarta, 2017). The advantages of farming in a hydropower system are: 1) Higher yields and crop quality; 2) More free from pests and diseases; 3) Use of water and fertilizer more efficiently; 4) Able to overcome land problems; 5) Can overcome the problem of land limitations. While the benefits are: 1) No tillage; 2) No need for crop rotation; 3) Uniform results; 4) Clean 5) High yields; 6) Labor-less (efficient); 7) Easier to maintain; 8) It's easier to replace a new factory; 9) Can be a place and way to improve plant quality

In East Java, the Hydroganic System was developed by the Mini Maxi Joint Business Group which formed the "Dream Workshop" association in Kanigoro Village, Pagelaran District, Malang District, and then was widely studied and disseminated through training and dissemination in various cities in Java and outside Java. The Hydroganic Technology Dissemination Program with independent electricity sources from solar power plants has been carried out in Grangsil Hamlet, Jambangan Village, Dampit District, Malang Regency. Communities that are the actors of the activities are the "KampoengBoengaGrangsil" Tourism Awareness Group and the "Syakura Arum" Farmer Women's Group. This activity is part of community-based development with the involvement of community participation which has now become a policy of rural development planning. Community participation in the process of planning and constructing agricultural facilities is based on community needs, priorities and affordability, which can result in more realistic and better designs, plans and programs. Participatory community approaches in developing ecotourism villages can reduce funding, increase the use of local resources, and empower community social capital (Wikantiyoso, R. at.al. 2019) Grangsil Hamlet, Jambangan Village, Malang Regency is a flower-based hamlet with character which has a high work ethic and a very high mutual cooperation community.

\section{Literature Review}

\subsection{Food Safety}

Food safety has five elements that must be met: (a) Household and individual oriented; (b) Time dimension at any time when food is available and accessible; (c) 
Emphasis on household and individual food access, both physical, economic and social; (d) oriented towards fulfilling nutrition; and (e) Aimed at healthy and productive living (Suharyanto, 2011). One aspect that can encourage increased food safety is the use of yards.

Utilization of a yard or a limited home page can have maximum added value if done properly and has a clear concept. The existing plots of land are generally not utilized to meet food needs, even if implemented, are still part-time or free time. Puspitasari (2018) states that it is necessary to design a more comprehensive yard utilization plan to optimize the role of the plot as a buffer for household food safety. Yard with diversity in it also has a great potential to increase the carrying capacity of the environment. The urban agriculture movement can be the backbone in increasing community independence, especially maintaining food safety at the household scale. The limited land area gave rise to the choice of farming with a hydroponic system.

\subsection{Bamboo Structure of Greenhouse}

Greenhouse buildings are used to create optimal conditions in crop cultivation activities in a controlled environment (Anadia, Nafila, at.al. 2018). The plastic material is needed for the cultivation of hydroponic plants. The function of a plastic material is as a regulator of solar radiation that enters the greenhouse, besides that it also serves as a protection against plants from insects and birds (Hendra, 2015).

Bamboo is a local material that is widely available throughout Indonesia and especially in rural areas. With careful and perfect processing (preserving) efforts, the material from this bamboo material can become a construction material with emulsions that are strong enough / hard and durable (durable), so that it can be used for various types of practical benefits (Handoko, 2014). Bamboo is also an ecological material that is easily rejuvenated and loaded with various benefits. All the elements that exist in the bamboo base (ranging from: stems, leaves, even to get the roots) can be widely used in various activities in daily community life.

\subsection{Hydroganic Agriculture System}

Hydroganic comes from the words "Hydro" and "Organic" which are defined as organic cultivation systems by combining the hydro system and the organic system. The main source of nutrition from hydroganic is obtained from solid and liquid organic fertilizer and pond water which is treated as plant nutrition (Yeniarta. 2017).

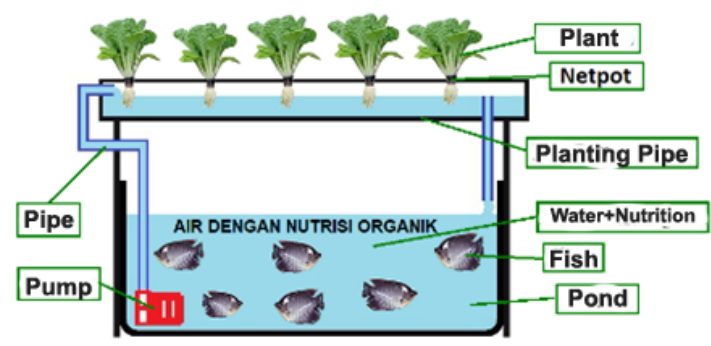

Figure 1.Hydroganic system

\subsection{Photovoltaic Solar Energy Systems}

The main component of a Solar Energy System is a photovoltaic cell that converts solar radiation into electricity directly (direct conversion) captured by the Solar Array, a 
The Bamboo Greenhouse Technology for Hydroganic Plants with Independent Photovoltaic

Energy in the Food Safety Program

Hery Budiyanto, Munanto Haris, Aries Boedi Setiawan, Elta Sonalitha,Muhammad Iqba

Balance of System (BOS) required includes a charge controller and inverter, an energy storage unit (battery) and other supporting equipment (Widayana, 2012). This energy system will support the electricity needs of circulating water pumps that pump water from ponds to the pipe pipes where hydropower vegetables are planted.

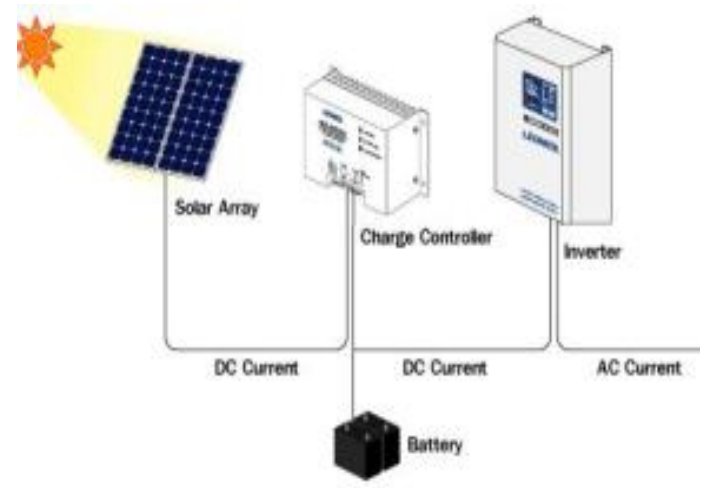

Figure 2. Photovoltaic Solar Energy Systems

Source: Widayana, 2012

\subsection{Research Methods}

This study uses descriptive qualitative methods and action research in the form of making a prototype of a greenhouse for hydroganic plants, conducting a trial of growing vegetables. The method of implementing technology dissemination activities to the community used in this activity are: a) lectures and discussions, namely providing knowledge and understanding of how to grow a hydroganic system and its benefits and benefits, discussion and questions and answers, the practice of hydropoweric farming; $b$ ) practice of making bamboo structures greenhouses; c) the practice of installing hydraulic plants; d) the practice of installing solar power plants; e) the practice of planting and maintaining vegetable plants in a hydroganic manner. The implementation was carried out in mutual cooperation by the people of Grangsil, Jambangan Village, Dampit District, Malang Regency. Lectures and discussions were held in several places according to the Village Head, in the Greenhouse, and at the "Dream Workshop", with the help of power point media and video; while the practice of growing vegetables and spreading fish seeds using hydroganic equipment.

Primary data in this study were taken with a variety of observations, namely: a) Greenhouse design, b) speed of greenhouse construction, c) speed of installation of hydroganic installations, d) Speed of solar power plan installation e). The workshop process The process of planting and maintaining vegetables.

\section{Results and Discussion}

\subsection{Design}

The design of Hydroganic Vegetable Farm Greenhouse with Solar Energy System was carried out by the Construction Team for 15 days. The shape of the building uses a tunnel shape that makes it easy for the community to build it. While the building structure uses bamboo material, remember that in Grangsil area there are many bamboo plants for building construction. 
The following figure shows a tunnel-shaped greenhouse design using bamboo structures with photovoltaic independent energy.

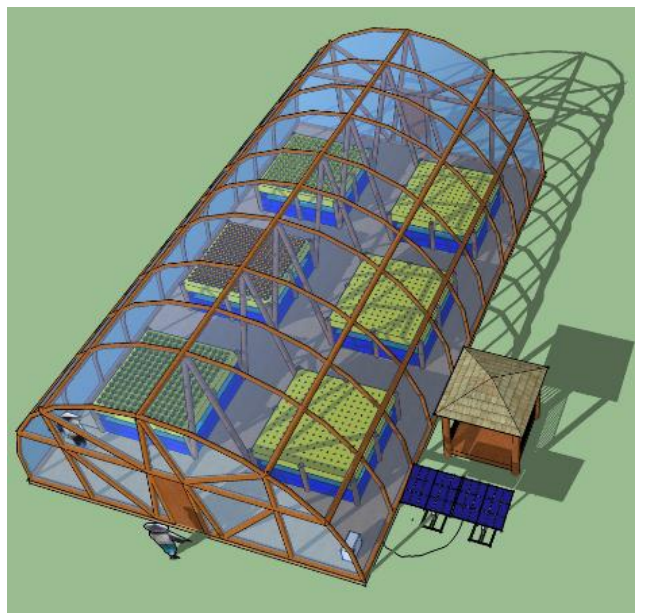

Figure 3. Design of a bamboo greenhouse for solar energy hydroganic agriculture (15 days)

\subsection{Construction}

\subsubsection{Construction of a Greenhouse}

The construction of a greenhouse with a bamboo structure was carried out cooperatively by the Grangsil hamlet community assisted by Unmer Malang students who were doing a Real Work Lecture. It takes 15 days to complete the construction of a greenhouse with a bamboo structure.

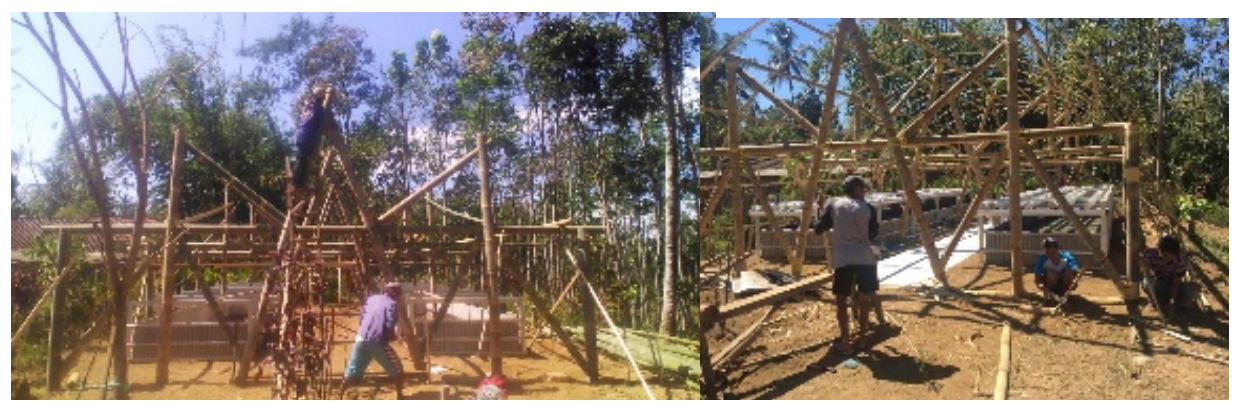

Figure 4. Construction of a Greenhouse (15 days)

\subsubsection{Hydroganic Installation}

Hydroganic installation with materials: aluminum frame, paralon pipe, asbestos wave, tarpaulin; The implementation was carried out by the Jambangan community and Malang Unmer Community Service students with direction from the Unmer Malang Community Service Team and hydroganic experts from "Dream Workshop. Installation of this facility takes 6 days. 
The Bamboo Greenhouse Technology for Hydroganic Plants with Independent Photovoltaic Energy in the Food Safety Program

Hery Budiyanto, Munanto Haris, Aries Boedi Setiawan, Elta Sonalitha,Muhammad Iqba

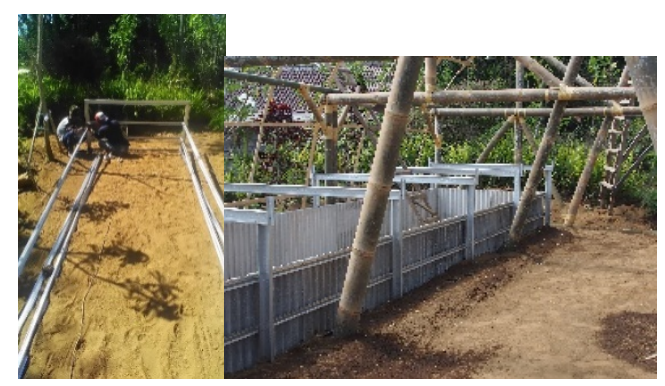

Figure 5. Hydroganic Installation (6 days)

\subsubsection{Solar Power Plan Installation}

Installation of Solar Power Plan installations include: solar panels, brackets, solar controllers, batteries, inverters, and cable networks leading to water pumps and lighting lamps carried out by the Unmer Malang Community Service Team assisted by the people of Jambangan Village. Installation is carried out within 2 days.

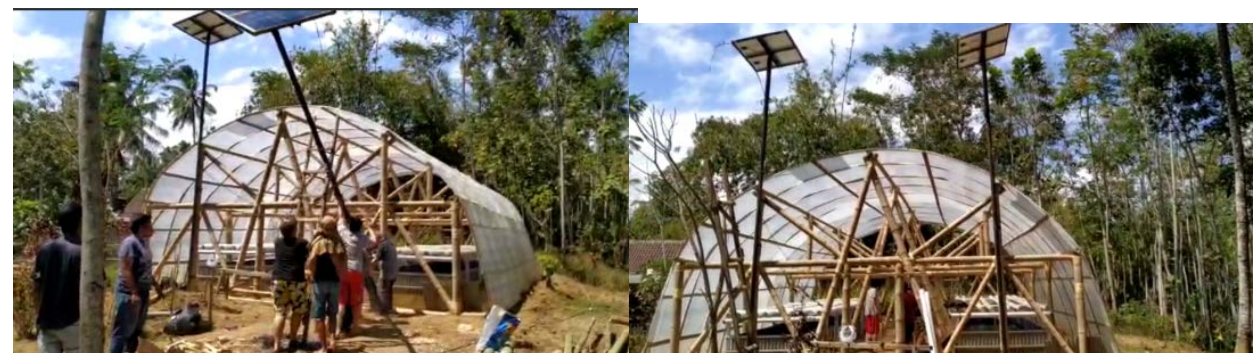

Figure 6: PLTS Installation (2 days)

\subsection{Socialization and Coordination}

\subsubsection{Coordination}

Discussions in the form of and coordination were carried out in the field where hydropower was planted and in the house of the Head of Grangsil Hamlet.

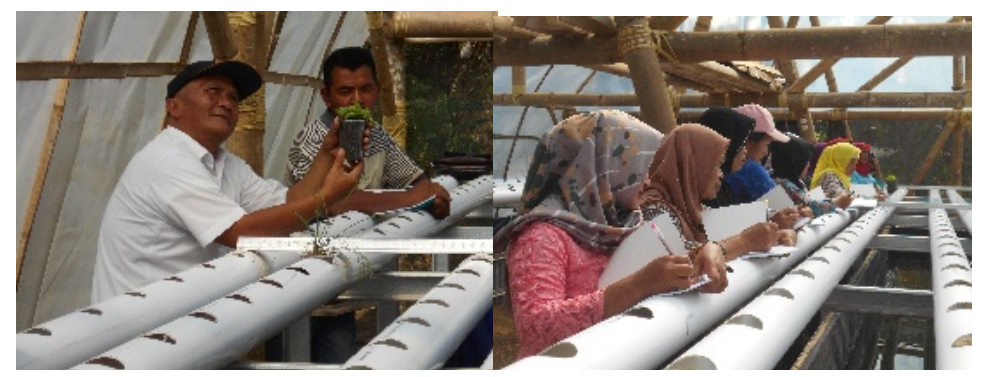

Figure 7. Socialization of Hydroganic Agriculture 


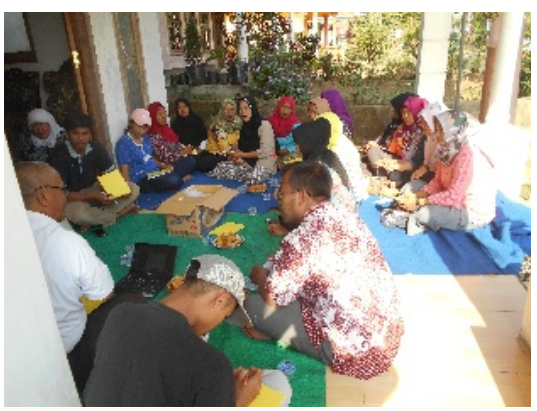

Figure 8. Coordination of the Hydroganic Management Team

\subsection{Hydroganic Agriculture Workshop}

Hydroganic agriculture workshops include: an understanding of hydroganic farming, how to make hydroganic media, how to plant and maintain hydropower plants carried out at the "Dream Workshop" in Kanigoro Village, Pagelaran District, Malang Regency.

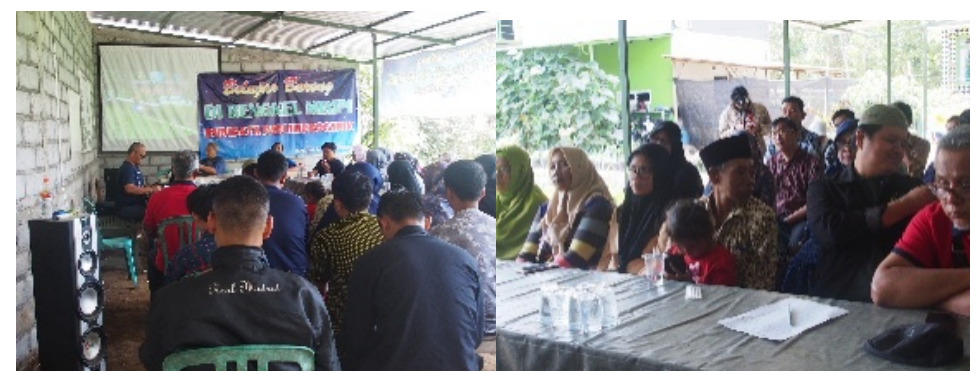

Figure 9.Hydroganic Agriculture Workshop

\subsection{Planting and Harvesting}

Planting lettuce and mustard greens as well as spreading catfish and tilapia in mid-August 2019, lettuce vegetables can be harvested at the end of September 2019. The success that can be seen is that when farmers cannot grow vegetables in dry land, the vegetable plants in this hydroganic greenhouse remain fertile and healthy because water circulation occurs continuously. Tunnel-shaped greenhouse with bamboo structure using independent energy for hydroponic farming is very practical, efficient and quick to build and can be planted with vegetables and spread fish throughout the year without pause is expected to be a prototype of modern agricultural and fishery facilities without relying on the rainy or dry season in the framework of the program increase national scale food safety.
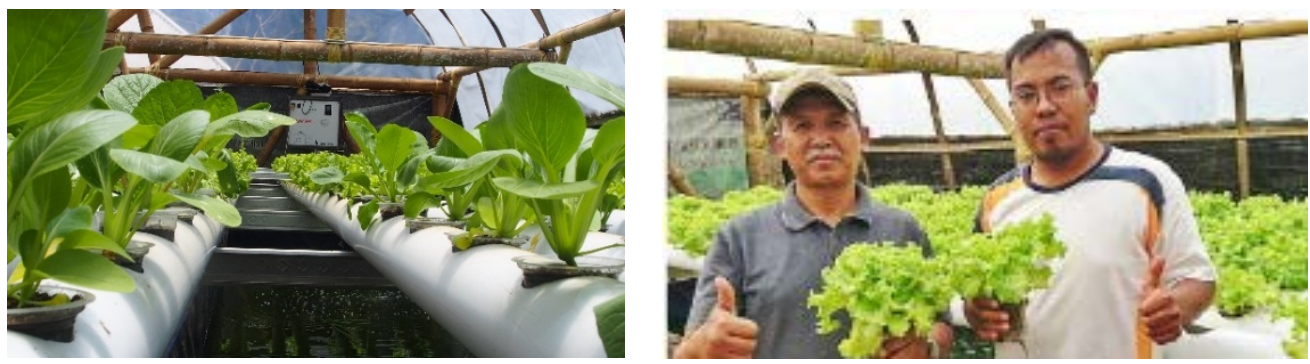

Figure 10. First Harvest of Lettuce Vegetable 
The Bamboo Greenhouse Technology for Hydroganic Plants with Independent Photovoltaic

Energy in the Food Safety Program

Hery Budiyanto, Munanto Haris, Aries Boedi Setiawan, Elta Sonalitha,Muhammad Iqba

\subsection{Photovoltaic solar energy testing}

The results of testing of each solar panel $100 \mathrm{wp}$ are as follows:

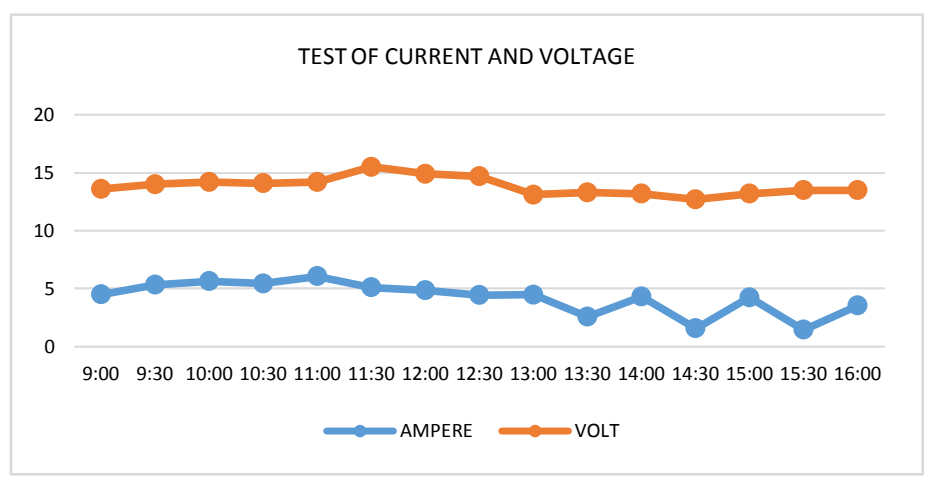

Figure 11. Graph of Current and Voltage of Solar Panels

In sunny weather, a $100 \mathrm{WP}$ solar panel can produce an average of 4.2 Ampere 13.8 Volts, whereas when the weather is cloudy the current drops to 1.4 Amper 6.07 Volts. Electrical energy stored in batteries can already be used to drive water pumps with a power of 38 Watt each 220 Volt voltage and lighting lamps both in the greenhouse and in the surrounding environment.

\section{Conclusions and Suggestions}

\subsection{Conclusions}

a. The Greenhouse prototype with tunnel shape and bamboo structure material is a choice of beautiful, sturdy, and comfortable building forms used for hydroganic farming. Hydroganic agriculture is an example of an effort to succeed in a program to improve food safety by utilizing increasingly narrow agricultural land.

b. Planting vegetables as well as spreading fish, can be harvested at two month after planting. The success that can be seen is that when farmers cannot grow vegetables in dry land, the vegetable plants in this hydroganic greenhouse remain fertile and healthy because water circulation occurs continuously.

c. Tunnel-shaped greenhouse with bamboo structure using independent energy for hydroponic farming is very practical, efficient and quick to build and can be planted with vegetables and spread fish throughout the year without pause is expected to be a prototype of modern agricultural and fishery facilities without relying on the rainy or dry season in the framework of the program increase national scale food safety.

d. Hydroganic agriculture with solar energy independent electricity is an example of a very efficient farming system and the use of independent energy. This technology is very suitable for the needs of modern agriculture. Electrical energy requirements for water pumps and lighting can be met by 4 photovoltaic solar cell panels, in sunny weather it produces 13.2 Amperes of electricity, 19.2 Volts, so it doesn't need a generator or PLN electricity. This independent energy hydroganic greenhouse building can become a widespread prototype as a greenhouse building that is quickly built with independent energy. 


\subsection{Suggestions}

a. Prototype of Greenhouse Agriculture Hydroganic solar energy independent electricity can be duplicated on a broader scale.

b. Further research can be done on the automation system in several parts to facilitate the hydroganic operation, including setting the time for fish feed and water circulation.

c. Further research can also be carried out on the use of bamboo as a substitute for paralon pipes for hydroganic farming.

\section{References}

Anadia, Nafila, at.al. (2018). "Greenhouse Structure and Functional Analysis".Teknotan Journal Vol. 12 No. 1, April 2018, P - ISSN: 1978-1067; E - ISSN: 2528-6285. Bandung: Faculty of Agricultural Industry Technology, Padjadjaran University.

Handoko.(2014). Bamboo Building Design: Worship Facilities for P4S TaniMandiri Farmer Community Cibodas Village, Lembang District, Bandung Regency. Community Service Grant. Bandung: LPPM Parahyangan Catholic University.

Hendra, Failasuf Herman. (2015). Designing Hydroponic plant cultivation facilities with a bioclimatic approach.National Seminar on Applied Science and Technology III 2015 ISBN 978-602-98569-1-0 Adhi Tama Institute of Technology Surabaya

Pratiwi, Y. I., Ali, M., Setiawan, M. I., Budiyanto, H., \&Sucahyo, B. S. (2017).Urban Agriculture Technology to Support Urban Tourism. ADRI International Journal of Agriculture, 1(1), 57-60. Retrieved from http://ejournal.padri.org/index.php/ijag/article/view/142

Puspitasari, Agnes. (2018). Hydroponic Agricultural Utilization to Overcome the Limitations of Agricultural Land in Urban Areas.National Seminar on Community Service.Open University. September 28, 2018.

Suharyanto, Heri. 2011. Food Security. Journal of Social Humanities, Vol. 4 No.2, November 2011.

Yeniarta. 2017. BBPP Ketindan Develops Organic Vegetables with "Hydroganics" (Organic Hydroponics). Agriculture Articles.No. 15. October 2017. The Center for Agricultural Research (BBPP) Ketindan Malang Regency.

Widayana, Gede. (2012). Utilization of Solar Energy.Journal of Technology and Vocational Education, Ganesha University of Education. Vol.9 no.1 (2012)

Wikantiyoso, R., Cahyaningsih, D. S., Sulaksono, A. G., \&Widayati, S. (2019). Sustainable Community Based Ecotourism Development; Grangsil Flower Village Tourism Park, Dampit District, Malang Regency. In SPSD 2019 Conference.SPSD Press. 